\title{
Comparative prebiotic activity of mixtures of cereal grain polysaccharides
}

\author{
Suzanne Harris ${ }^{1,2^{*}}$, Andrea Monteagudo-Mera' ${ }^{1}$, Ondrej Kosik², Dimitris Charalampopoulos ${ }^{1}$, Peter Shewry ${ }^{1,2}$ \\ and Alison Lovegrove ${ }^{2}$
}

\begin{abstract}
The main components of the non-starch polysaccharide (NSP) fraction of wheat flour are arabinoxylan (AX) and $\beta$-glucan. These are also present in other cereal grains, but their proportions vary with AX being the major component in wheat and rye and $\beta$-glucan in barley and oats. Therefore, it was hypothesised that these NSPs could act synergistically when fermented in vitro at the ratios present in the major foods consumed, resulting in increased prebiotic activity. AX and $\beta$-glucan were therefore tested in in vitro fermentation studies to assess their prebiotic activity when used individually and/or in different ratios. Short-chain fatty-acids (SCFAs) produced from in vitro fermentation were measured using HPLC and bacterial populations were measured using flow cytometry with fluorescence in situ hybridisation (Flow-FISH). Fermentation of AX alone resulted in a significant bifidogenic activity and increased concentrations of SCFAs, mainly acetate, after 8-24 h of fermentation, however $\beta$-glucan alone did not show prebiotic activity. The greatest prebiotic activity, based on concentration of total SCFAs and increases in total bacteria as well as beneficial Bifidobacterium and Clostridium coccoides/Eubacterium groups, was observed when AX and $\beta$-glucan were combined at a 3:1 ratio, which corresponds to their ratios in wheat flour which is major source of cereal fibre in the diet. This indicates that the population of bacteria in the human Gl tract may be modulated by the composition of the fibre in the diet, to maximise the prebiotic potential.
\end{abstract}

Keywords: Prebiotic, Batch culture, Fluorescence in situ hybridisation (FISH), Short chain fatty acids (SCFA), $\beta$-Glucan, Arabinoxylan

\section{Introduction}

Wheat is most important cereal in terms of global consumption, being the staple food crop in temperate countries and increasingly replacing traditional crops in sub-Saharan Africa and Asia. Wheat is usually consumed after processing into two types of food: as bread and other baked goods and as noodles or pasta. In most cases these are produced from white flour which is made from the endosperm and contains around $2-3 \%$ total dietary fibre (TDF) compared with wholemeal which also contains the outer bran layers and contains about 11.5 to 15.5\% TDF (Shewry and Hey 2015). Nevertheless, white

\footnotetext{
*Correspondence: Suzanne.harris@crick.ac.uk

${ }^{1}$ Department of Food and Nutritional Sciences, University of Reading,

Whiteknights, PO Box 226, Reading RG6 6AP, UK

Full list of author information is available at the end of the article
}

bread contributes about $10 \%$ of the TDF in the adult UK diet (Steer et al. 2008), and correspondingly more in regions such as North Africa and Central Asia where wheat can account for between 50 and $70 \%$ of the total energy intake. Hence, the biological activity of wheat flour fibre is of significant interest, including their properties as a prebiotic (which can be defined as 'non-digestible (by the host) food ingredients that have a beneficial effect through their selective metabolism in the intestinal tract' (Gibson et al. 2017).

The major dietary fibre (DF) components in wheat flour are cell wall polysaccharides, fructans, resistant starch and the arabinogalactan peptide. Fructans account for 1-2\% of white flour (Haskå et al. 2008) and have well-established prebiotic properties, while the level of resistant starch is low $(<0.1 \%)$ compared to nonstarch polysaccharides (Siljeström and Asp 1985). The
Springer Open (c) The Author(s) 2019. This article is licensed under a Creative Commons Attribution 4.0 International License, which permits use, sharing, adaptation, distribution and reproduction in any medium or format, as long as you give appropriate credit to the original author(s) and the source, provide a link to the Creative Commons licence, and indicate if changes were made. The images or other third party material in this article are included in the article's Creative Commons licence, unless indicated otherwise in a credit line to the material. If material is not included in the article's Creative Commons licence and your intended use is not permitted by statutory regulation or exceeds the permitted use, you will need to obtain permission directly from the copyright holder. To view a copy of this licence, visit http://creativeco mmons.org/licenses/by/4.0/. 
cell wall polysaccharides of wheat flour comprise two major components, about $70 \%$ arabinoxylan (AX) and $20 \%(1 \rightarrow 3,1 \rightarrow 4)-\beta$-D-glucan ( $\beta$-glucan), with about $2 \%$ cellulose $((1 \rightarrow 4)-\beta$-D-glucan $)$ and $7 \%$ glucomannan (Mares and Stone 1973). AX comprises a backbone of $\beta$-D-xylopyranosyl residues linked through $(1 \rightarrow 4)$ glycosidic linkages with some residues being substituted with $\alpha$-L-arabinofuranosyl residues at either position 3 or positions 2 and 3 (Fincher and Stone 1974). Some arabinofuranosyl residues at position 3 of the xylan residues may themselves be substituted with ferulic acid at the 5 position which allows the formation of cross-links, by oxidation of ferulate present on adjacent AX chains to give dehydrodimers (diferulates). AX occurs in watersoluble and insoluble forms, which may differ in their molecular weight, degree of substitution, and extent of diferulate cross-linking. $\beta$-glucan has a simpler structure, comprising only glucose residues joined by $(1 \rightarrow 3)$ and $(1 \rightarrow 4)$ linkages. Single $(1 \rightarrow 3)$ linkages are usually separated by two or three $(1 \rightarrow 4)$ linkages but longer stretches of $(1 \rightarrow 4)$ linked glucan of up to 14 units have been reported for wheat bran $\beta$-glucan (Li et al. 2006). Such regions are sometimes referred to as "cellulose-like", as cellulose is $(1 \rightarrow 4)-\beta$-D-glucan without any $(1 \rightarrow 3)$ linkages. $\beta$-Glucan occurs in soluble and insoluble forms, which may differ in their size and distribution of $(1 \rightarrow 3)$ and $(1 \rightarrow 4)$ linkages (Johansson et al. 2004).

Several previous studies of the prebiotic effects of AX from wheat and $\beta$-glucan from barley have been reported (Hughes et al. 2007, 2008; Wang et al. 2016). However, should be noted that these components are not consumed singly in human diets but as mixtures in complex foods. In particular, AX and $\beta$-glucan are most widely consumed in a ratio of about 3:1 in bread and other wheat products and it is therefore possible that the human colonic microflora has adapted to provide more efficient fermentation of this ratio. We have therefore compared the fermentation of AX and $\beta$-glucan as single compounds with mixtures at ratios of $1: 3,1: 1$ and 3:1.

\section{Materials and methods}

\section{Materials}

Wheat arabinoxylan (P-WAXYM) and barley $\beta$-glucan preparations (P-BGBH) were purchased from Megazyme (Bray, co. Wicklow, Ireland).

\section{In-vitro fermentation}

$100 \mathrm{~mL}$ sterile batch fermentation vessels $(50 \mathrm{~mL}$ working volume) were aseptically filled with $45 \mathrm{~mL}$ of sterile basal medium and sparged with $\mathrm{O}_{2}$-free $\mathrm{N}_{2}$ overnight to establish anaerobic conditions. The medium contained per litre: $2 \mathrm{~g}$ of peptone water (Oxoid Ltd., Basingstoke, United Kingdom), $2 \mathrm{~g}$ of yeast extract (Oxoid),
$0.1 \mathrm{~g}$ of NaCl, $0.04 \mathrm{~g}$ of $\mathrm{K}_{2} \mathrm{HPO}_{4}, 0.01 \mathrm{~g}$ of $\mathrm{MgSO}_{4} \cdot 7 \mathrm{H}_{2} \mathrm{O}$, $0.01 \mathrm{~g}$ of $\mathrm{CaCl}_{2} \cdot 6 \mathrm{H}_{2} \mathrm{O}, 2 \mathrm{~g}$ of $\mathrm{NaHCO}_{3}, 0.005 \mathrm{~g}$ of hemein (Sigma), $0.5 \mathrm{~g}$ of L-cysteine $\mathrm{HCl}$ (Sigma), $0.5 \mathrm{~g}$ of bile salts (Oxoid), $2 \mathrm{~mL}$ of Tween 80, $10 \mu \mathrm{L}$ of vitamin K (Sigma). Polysaccharide samples were added $(1 \% \mathrm{w} / \mathrm{v})$ to the basal medium. Each vessel was inoculated with $10 \%(\mathrm{v} / \mathrm{v})$ of faecal slurry, which was prepared by homogenizing fresh human faeces $(10 \%, w / w)$ in phosphate-buffered saline (PBS; $8 \mathrm{~g} / \mathrm{L} \mathrm{NaCl}, 0.2 \mathrm{~g} / \mathrm{L} \mathrm{KCl}, 1.15 \mathrm{~g} / \mathrm{L} \mathrm{Na} \mathrm{HPO}_{4}$, and $0.2 \mathrm{~g} / \mathrm{L} \mathrm{KH}_{2} \mathrm{HPO}_{4}$ ), pH 7.3 (Oxoid), using a stomacher (Stomacher 400, Seward). Three individual faecal donors were used per experiment and samples were not pooled, donors were two female and one male, between 23 and 59 years of age and on a normal diet without any special dietary requirements and that had not taken antibiotics, prebiotic or probiotics in the previous 3 months. Vessels were incubated at $37^{\circ} \mathrm{C}$ with a water jacket for up to $48 \mathrm{~h}$ and the $\mathrm{pH}$ was controlled between 6.7 and 6.9 with $0.5 \mathrm{M} \mathrm{HCl}$ and $0.5 \mathrm{M} \mathrm{NaOH}$ using an automated $\mathrm{pH}$ controller (Fermac 260, Electrolab, Tewkesbury, UK). Samples were collected at $0,4,8,24 \mathrm{~h}$ for analysis.

\section{SCFA analysis using HPLC}

Samples were centrifuged at $13,000 \times g$ for $5 \mathrm{~min}$ to remove particulate matter and filtered using $0.2 \mu \mathrm{M}$ nitrocellulose filter. $20 \mu \mathrm{L}$ was injected on to a Phenomenex Rezex ROA Organic Acid $\mathrm{H}^{+}(8 \%)$ HPLC column (Watford, UK) at $50{ }^{\circ} \mathrm{C}$ on a Shimadzu HPLC with $0.0025 \mathrm{M} \mathrm{H}_{2} \mathrm{SO}_{4}$ eluent at a flow rate of $0.6 \mathrm{~mL} / \mathrm{min}$. SCFA (lactate, formate, acetate, propionate and butyrate) were quantified using standard calibration curves from 1 to $100 \mathrm{mM}$.

\section{Enumeration of bacteria by flow-FISH}

Samples were centrifuged at $10,000 \times g$ for $3 \mathrm{~min}$ and supernatant discarded. Pelleted sample was fixed for $4 \mathrm{~h}$ at $4{ }^{\circ} \mathrm{C}$ with $4 \%(\mathrm{w} / \mathrm{v})$ filtered paraformaldehyde (pH 7.2) in a ratio of 1:3 $(\mathrm{v} / \mathrm{v})$. Samples were washed twice with filtered PBS and resuspended in $600 \mu \mathrm{L}$ of a mixture of PBS/ethanol $(1: 1, \mathrm{v} / \mathrm{v})$ and then stored at $-20{ }^{\circ} \mathrm{C}$ for up to 3 months. Hybridisation was carried out as described in Rycroft et al. (2001a, b) using genus and group specific 16S rRNA-targeted oligonucleotide probes (MWG Biotech, Ebersberg, Germany).

The sample probes used were Bif164 (Langendijk et al. 1995), Bac303 (Manz et al. 1996), Lab158 (Harmsen et al. 2000), Ato291 ${ }^{3}$, Prop853 (Walker et al. 2005), Erec482 (Franks et al. 1998), Rrec584 (Walker et al. 2005), Fprau655 (Hold et al. 2003), Chis 150 (Franks et al. 1998), shown in Additional file 1: Table S1. Samples were screened using a flow cytometer (Accuri C6, BD Biosciences, USA) with Accuri CFlow software. 


\section{Statistical analysis}

Statistical analyses were performed using SPSS for Windows, version 21. Univariate analysis of variance and Tukey's post hoc test was used to determine significant changes between treatments in the microbiota populations and SCFA concentrations. Differences were considered significant when $\mathrm{P}<0.05$.

\section{Results}

\section{Production of SCFA}

Figure 1 and Additional file 1: Table S2 show the concentrations of SCFAs and lactate in samples incubated with: AX alone, AX: $\beta$-glucan (3:1, w/w), AX: $\beta$-glucan $(1: 1, w / w), A X: \beta$-glucan $(1: 3, w / w), \beta$-glucan alone and FOS after $24 \mathrm{~h}$ ' fermentation. Fermentation of the samples containing AX, AX: $\beta$-glucan (3:1), AX: $\beta$-glucan (1:1), and FOS had significantly higher concentrations of total SCFAs $(\mathrm{P}>0.95)$ compared to the negative control, mainly due to production of acetate. The greatest increase in acetate concentration was observed with $\mathrm{AX}$ and $\mathrm{AX}$ : $\beta$-glucan (3:1) from 8 to $24 \mathrm{~h}$, and with AX: $\beta$-glucan (1:1) at $8 \mathrm{~h}$. By contrast, the acetate concentrations were not significantly increased compared to the control sample with AX: $\beta$-glucan (1:3) or $\beta$-glucan alone. While the mean butyrate concentration was increased after $24 \mathrm{~h}$ fermentation with FOS, AX, AX: $\beta$-glucan (3:1), and AX: $\beta$-glucan (1:1), these increases were not statistically significant due to large variation between donors.

Table 1 shows the percentages of individual SCFAs produced after $24 \mathrm{~h}$ fermentation. The proportions of SCFAs differ between substrates, with those comprising high proportions of AX producing greater proportions of acetate and those containing greater levels of $\beta$-glucan producing greater proportions of propionate. The proportion of butyrate produced did not differ.

\section{Bacterial populations}

The populations of the dominant types of human colonic bacteria after in vitro fermentation with $\mathrm{AX}$ alone, AX: $\beta$-glucan (3:1), AX: $\beta$-glucan (1:1), AX: $\beta$-glucan (1:3), $\beta$-glucan alone and FOS are shown in Additional file 1: Table S3, while the populations which changed significantly compared with the negative control (Total bacteria, Bifidobacterium, Clostridium coccoides/Eubacterium

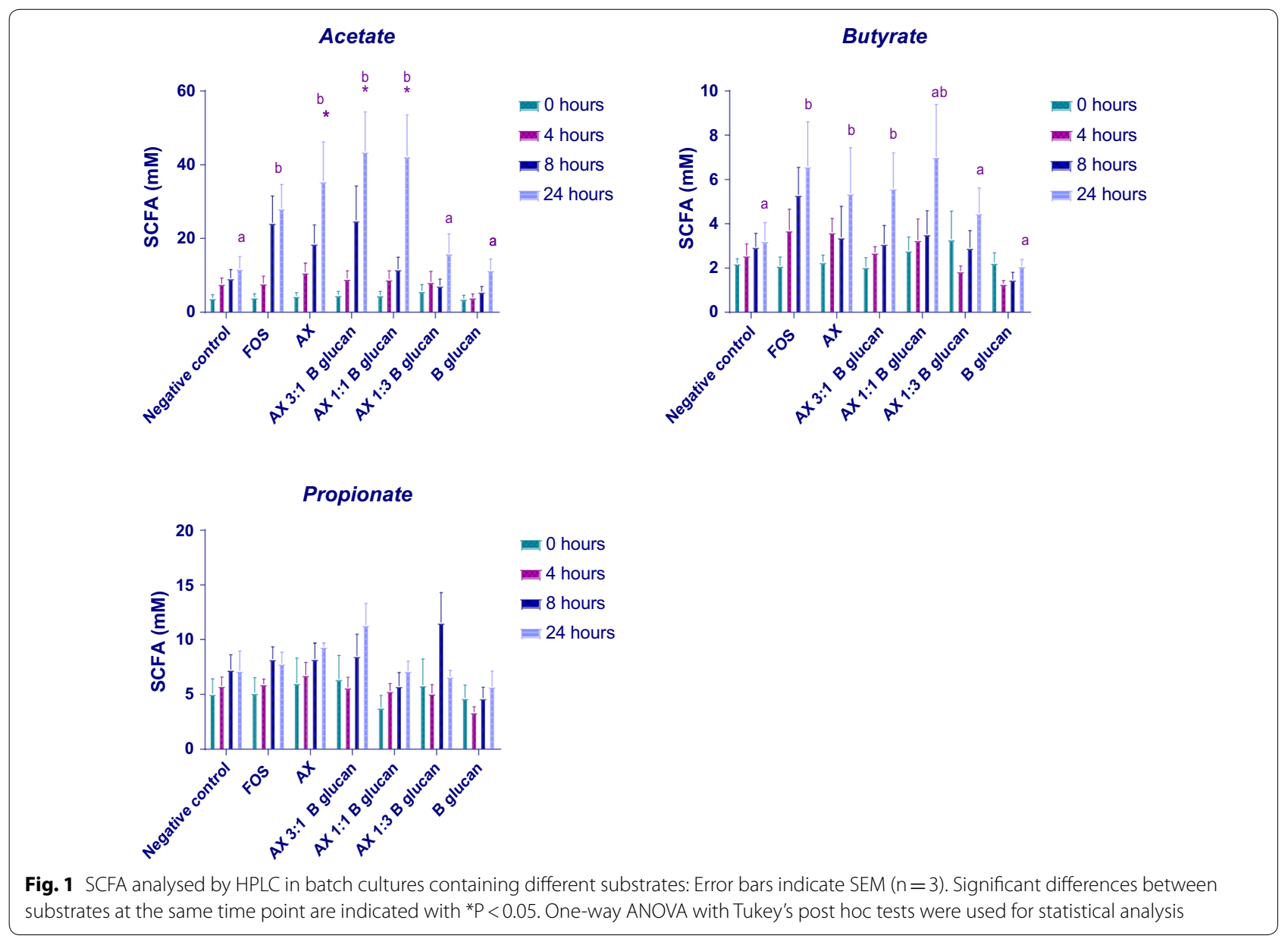


Table $1 \%$ SCFA produced in in vitro colonic fermentation vessels at $24 \mathrm{~h}$ containing $A X$ and $\beta$-glucan alone and combined in different ratios

\begin{tabular}{|c|c|c|c|}
\hline & SCFA (\%) & & \\
\hline & Acetate & Propionate & Butyrate \\
\hline No treatment & $47.2( \pm 13.5)$ & $37.0( \pm 7.8)$ & $15.7( \pm 4.1)$ \\
\hline FOS & $70.0( \pm 8.0)$ & $15.4( \pm 4.3)$ & $14.6( \pm 4.6)$ \\
\hline$A X$ & $73.5( \pm 16.1)$ & $15.4( \pm 3.6)$ & $11.1( \pm 4.3)$ \\
\hline AX 3:1 $\beta$-glucan & $74.9( \pm 10.6)$ & $15.5( \pm 4.7)$ & $9.6( \pm 2.8)$ \\
\hline AX 1:1 $\beta$-glucan & $72.0( \pm 25.3)$ & $12.0( \pm 3.7)$ & $15.9( \pm 5.4)$ \\
\hline AX 1:3 $\beta$-glucan & $63.0( \pm 16.5)$ & $19.3( \pm 5.7)$ & $17.7( \pm 4.5)$ \\
\hline$\beta$-Glucan & $45.3( \pm 10.3)$ & $44.9( \pm 17.5)$ & $9.7( \pm 1.3)$ \\
\hline
\end{tabular}

FOS is the positive control, and no added polysaccharide (no treatment) is the negative control, $\mathrm{n}=3$

rectale and Roseburia) are shown in Fig. 2. AX, AX: $\beta$-glucan (3:1) and AX: $\beta$-glucan (1:1) had significant $(P<0.05)$ bifidogenic effects between 8 and $24 \mathrm{~h}$ while the same three substrates gave significant increases Clostridium coccoides/Eubacteium rectale compared to the negative control $(\mathrm{P}<0.05)$ after $24 \mathrm{~h}$. The populations of Roseburia populations also increased significantly compared to the negative control $(\mathrm{P}<0.05)$ with fermentation of AX and AX: $\beta$-glucan (3:1) after $24 \mathrm{~h}$. Total bacterial populations included genera that were not specifically targeted with fluorescent probes, AX and AX: $\beta$-glucan $(1: 1)$ showed significant $(\mathrm{P}<0.05)$ increases in total bacteria after $24 \mathrm{~h}$, however AX: $\beta$-glucan (3:1) demonstrated earlier increases between 8 and $24 \mathrm{~h}$.

\section{Discussion}

This study aimed to determine the prebiotic activity of $\mathrm{AX}$ and $\beta$-glucan in combination and in different ratios in order to determine the optimal ratio of AX: $\beta$-glucan for the highest prebiotic activity.

A prebiotic is defined as a substrate that is selectively utilized by host microorganisms conferring a health benefit (Gibson et al. 2017) and the two major types of dietary fibre present in cereal grains have been shown to have prebiotic activity: wheat AX (Grootaert et al. 2009; Hughes et al. 2007; Van Craeyveld et al. 2008) and barley $\beta$-glucan (Hughes et al. 2008; Wang et al. 2016).

Short-chain fatty acids (SCFA) are volatile fatty acids consisting of a straight-chain aliphatic tail of fewer than six carbon atoms and are produced by oligosaccharide fermentation concomitant with increase in beneficial bacteria including Bifidobacterium. Their production is therefore used to measure prebiotic activity together

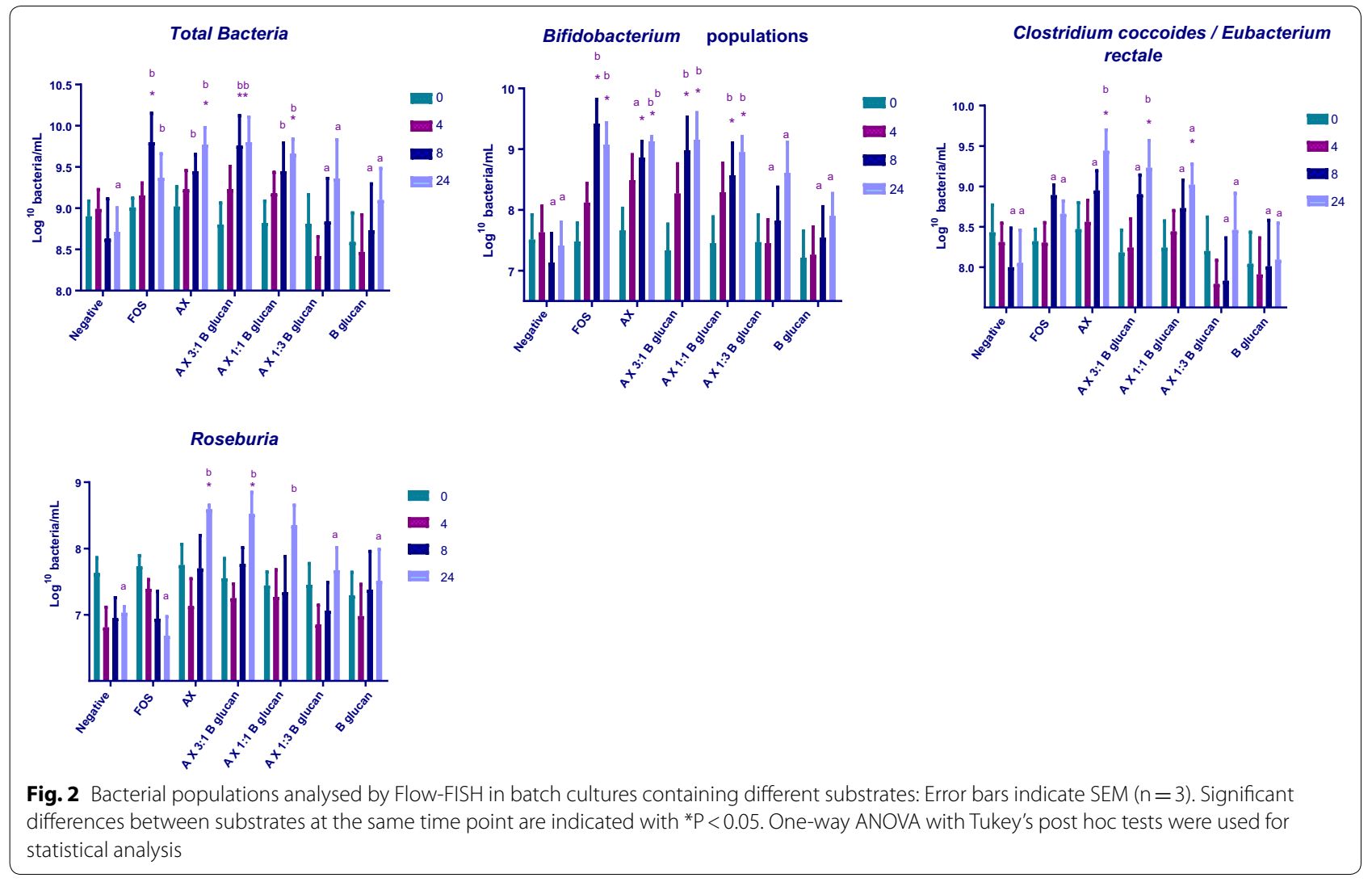


with beneficial changes in the microbiota. The principal SCFAs produced are acetate, propionate and butyrate (comprising 95\% of the total) (Cummings et al. 1987) and are metabolized by the colonic epithelium (butyrate), liver (propionate) and muscle (acetate) (Cummings and Macfarlane 1997). Relatively little is known about the role of formate in the gut, however it has been linked to methanogenesis and appears to be elevated in inflammatory conditions (Bereswill et al. 2011; Vanderhaeghen et al. 2015). SCFAs have been shown to provide multiple beneficial effects for the host, for example, providing dietary energy and suppressing the growth of pathogens by decreasing the $\mathrm{pH}$ of the intestinal lumen (Blaut 2002). The concentration of SCFAs in this study was used to measure the rate of fermentation of the substrates, with significant increases particularly apparent in the predominant SCFA, acetate, which is often utilised to produce other SCFAs, butyrate and propionate.

Acetate was the highest contributor of total SCFA for all samples. The addition of larger amounts of AX appears to drive the concentration towards greater acetate production (Table 1), whereas greater $\beta$-glucan appears to favour propionate production. The highest proportion of propionate is seen with the $\beta$-glucan sample alone at $44.9 \%$ (although this is at a significantly lower concentration than acetate). Previous studies have shown fermentation of $\beta$-glucan to favour production of propionate and fermentation of $\mathrm{AX}$ to encourage acetate and butyrate (Hughes et al. 2007, 2008) and these results corroborate these previous findings.

The bacterial genus Bifidobacterium is most often targeted by prebiotics, as it is associated with multiple health benefits, including reducing the proliferation of colorectal cancer and the concentration of circulating cholesterol (Singh 1997; Zanotti et al. 2015). Increases in Bifidobacterium populations were observed with the samples AX, AX: $\beta$-glucan (3:1), AX: $\beta$-glucan (1:1) and FOS (the positive control). Only FOS and the samples containing $\mathrm{AX}$ at a concentration of least $50 \%$ showed an increase in bifidobacteria, demonstrating a bifidogenic effect for AX but not $\beta$-glucan and supporting previous studies which showed that fermentation of oat and barley $\beta$-glucans had no effect on Bifidobacterium populations, whilst AX fermentation resulted in increases in Bifidobacterium populations (Hughes et al. 2007, 2008; Kim and White 2009). Concomitant increases in acetate were observed in all samples, which is consistent with the established role of bifidobacteria in acetate production (Bindels et al. 2015; Fukuda et al. 2011).

The structures of fermentable carbohydrates, including the degree of polymerisation (DP) and molecular weight, have previously been shown to affect the rate of fermentation (Hughes et al. 2007) and FOS is thought to be rapidly fermented due to its low DP (Stewart et al. 2008). In this study, the molecular masses of the AX (323 kDa) and $\beta$-glucan $(491 \mathrm{kDa})$ were much greater than that of FOS (DP 2-8). The longer polysaccharides in AX and $\beta$-glucan contain fewer non-reducing ends per unit mass than FOS, providing less substrate for hydrolysis by bacterial enzymes. However, a slower rate of fermentation could be beneficial slow-fermenting prebiotic may be able to reach the more distal regions of the colon, where the fermentable carbohydrate levels are much lower, and fermentation of proteins is more prevalent, and therefore have a greater impact on colonic health (Govers et al. 1999; Grootaert et al. 2009). The increase in total bacteria in samples with greater proportions of AX [AX, AX: $\beta$-glucan (3:1), AX: $\beta$-glucan (1:1)] were more sustained than with FOS, peaking at $24 \mathrm{~h}$ compared to $8 \mathrm{~h}$ with FOS and demonstrating greater persistence. The AX: $\beta$-glucan (3:1) sample showed significant increases from the negative control after $8 \mathrm{~h}$ and continued until $24 \mathrm{~h}$, therefore demonstrating the most sustained fermentation.

The increases in bifidobacteria were sustained between 8 and $24 \mathrm{~h}$ with AX and AX: $\beta$-glucan (3:1). The populations of Clostridium coccoides/Eubacterium rectales were also highest in both the AX and AX: $\beta$-glucan (3:1) samples at $24 \mathrm{~h}$. The increased populations of these bacterial groups at later fermentation times therefore demonstrates longer fermentation of samples containing higher levels of AX.

Similar increases in Bifidobacterium, Clostridium coccoides/Eubacterium rectales and Roseburia populations resulted from fermentation of $\mathrm{AX}$ alone and a 3:1 combination of $A X$ and $\beta$-glucan, as well as similar production of SCFAs. However, samples with AX: $\beta$-glucan (1:3) and $\beta$-glucan singly did not cause increases in beneficial bacterial groups of SCFAs It has been proposed that three colonic Bacteroides species: Bacteroides thetaiotaiomicron, Bacteroides distasonis and Bacteroides fragilis are responsible for the majority of $\beta$-D- $(1 \rightarrow 3)$-glucanase activity required for $\beta$-glucan hydrolysis (Salyers et al. 1997), however no significant increases were observed in the Bacteroides group with any combination of substrates. These results may be explained by a low prevalence of these particular Bacteroides species in the samples, and therefore a low level of $\beta$-glucan fermentation.

Butyrate is produced by a range of bacteria including the Clostridium, Roseburia and Eubacterium genera (Barcenilla et al. 2000; Gibson 1999; Pryde et al. 2002). Despite the increase in these butyrogenic bacterial populations with $\mathrm{AX}$ and $\mathrm{AX}$ and $\beta$-glucan (3:1), and a large rise in mean butyrate concentration, there were no significant concomitant increase in butyrate. However, closer inspection of the data shows that donors 1 and 3 responded to fermentation of all samples containing AX 
with production of butyrate, whilst butyrate production with donor 2 only responded to fermentation of FOS. Hence, the failure to observe significant increases in butyrate resulted in differences between individual donors.

The greatest increases in total bacterial numbers were observed with both the AX alone and the AX: $\beta$-glucan (3:1) sample, while no increase in bacterial numbers occurred when $\beta$-glucan alone was used, suggesting that AX is more readily used as a substrate for growth by bacteria than $\beta$-glucan. As the ratio of AX: $\beta$-glucan is greater in wheat (3:1) than barley (1:3), these data supports a previous study which showed that a wheat-based diet in pigs resulted in a greater increase in gut bacteria than a barley-based diet (Garry et al. 2007).

Thus, it appears that AX is readily used as a substrate for fermentation, at a greater rate than $\beta$-glucan, as previously described (Hughes et al. 2007, 2008) and that total bacterial numbers, and the Bifidobacterium, Roseburia and Clostridium coccoides-Eubacterium rectale bacterial groups show preferential growth with $\mathrm{AX}$ as a substrate. However, AX supplemented with $\beta$-glucan in a ratio of 3:1 showed similar increases in these bacterial populations and slightly greater SCFA concentrations as well as greater increases in total bacteria compared to $\mathrm{AX}$ alone, indicating that replacing $25 \% \mathrm{AX}$ as a fermentable substrate with $25 \% \beta$-glucan can potentially increase prebiotic activity. Any greater replacement of AX was shown to result in decreases in bacterial populations and SCFA. Wheat has been widely consumed by humankind for thousands of years, we therefore hypothesised that the human gut microbiota may have co-evolved to ferment the ratio of DF polysaccharides present in wheat more efficiently than other ratios of polysaccharides. The results reported here provide support for this hypothesis, as beneficial bacteria were shown to preferentially ferment AX compared to $\beta$-glucan with the preferred ratio of AX: $\beta$-glucan being that present in wheat $(3: 1)$.

\section{Supplementary information}

Supplementary information accompanies this paper at https://doi. org/10.1186/s13568-019-0925-z.

Additional file 1. Tables containing information on fluorescence in situ hybridisation probes used in the study. Tables containing data points for SCFA concentrations and bacterial populations after fermentation experiments.

\section{Authors' contributions}

SH: Investigation; methodology; analysis writing- original draft; writing-review and editing. AMM: methodology; analysis; writing-review and editing. OK: methodology; writing-review and editing. DC: conceptualization; funding; supervision; writing-review and editing PS: conceptualization; funding; supervision; writing-review and editing. AL: conceptualization; funding; supervision; writing-review and editing. This article does not contain any studies with human participants or animals performed by any of the authors. All authors read and approved the final manuscript.

Funding

Funding for the Ph.D. project that provided this study was obtained from the BBSRC, Lawes Agricultural trust and Reading University.

\section{Availability of data and materials}

Original data sets will not be shared as it is not a funder requirement.

\section{Ethics approval and consent to participate}

Not applicable.

\section{Consent for publication}

All authors consent to publication.

\section{Competing interests}

The authors declare that they have no competing interests.

\section{Author details}

${ }^{1}$ Department of Food and Nutritional Sciences, University of Reading, Whiteknights, PO Box 226, Reading RG6 6AP, UK. ${ }^{2}$ Department of Plant Science, Rothamsted Research, Harpenden AL5 2JQ, Hertfordshire, UK.

Received: 26 June 2019 Accepted: 3 December 2019

Published online: 21 December 2019

\section{References}

Barcenilla A, Pryde SE, Martin JC, Duncan SH, Stewart CS, Henderson C, Flint HJ (2000) Phylogenetic relationships of butyrate-producing bacteria from the human gut. Appl Environ Microbiol 66:1654-1661

Bereswill S, Fischer A, Plickert R, Haag L-M, Otto B, Kühl AA, Dashti Jl, Zautner AE, Muñoz M, Loddenkemper C (2011) Novel murine infection models provide deep insights into the "menage a trois" of Campylobacter jejuni, microbiota and host innate immunity. PLoS ONE 6:e20953

Bindels LB, Delzenne NM, Cani PD, Walter J (2015) Towards a more comprehensive concept for prebiotics. Nat Rev Gastroenterol Hepatol. 12:303-310

Blaut M (2002) Relationship of prebiotics and food to intestinal microflora. Eur J Nutr 41:i11-i16

Cummings JH, Macfarlane GT (1997) Collaborative JPEN-clinical nutrition scientific publications role of intestinal bacteria in nutrient metabolism. J Parenter Enter Nutr. 21:357-365

Cummings JH, Pomare EW, Branch WJ, Naylor CP, Macfarlane GT (1987) Short chain fatty acids in human large intestine, portal, hepatic and venous blood. Gut 28:1221-1227

Fincher GB, Stone BA (1974) A Water-soluble arabinogalactan-peptide from wheat endosperm. Aust J Biol Sci. 27:117-132

Franks AH, Harmsen HJM, Raangs GC, Jansen GJ, Schut F, Welling GW (1998) Variations of bacterial populations in human feces measured by fluorescent in situ hybridization with group-specific 16S rRNA-targeted oligonucleotide probes. Appl Environ Microbiol 64:3336-3345

Fukuda S, Toh H, Hase K, Oshima K, Nakanishi Y, Yoshimura K, Tobe T, Clarke JM, Topping DL, Suzuki T et al (2011) Bifidobacteria can protect from enteropathogenic infection through production of acetate. Nature 469:543-547

Garry BP, Fogarty M, Curran TP, O'Connell MJ, O'Doherty JV (2007) The effect of cereal type and enzyme addition on pig performance, intestinal microflora, and ammonia and odour emissions. Animal 1:751-757

Gibson GR (1999) Dietary modulation of the human gut microflora using the prebiotics oligofructose and inulin. J Nutr 129:1438S-1441S

Gibson GR, Hutkins R, Sanders ME, Prescott SL, Reimer RA, Salminen SJ, Scott K, Stanton C, Swanson KS, Cani PD et al (2017) Expert consensus document: the international scientific association for probiotics and prebiotics (ISAPP) consensus statement on the definition and scope of prebiotics. Nat Rev Gastroenterol Hepatol. 14:491-502

Govers aP, Gannon NJ, Dunshea FR, Gibson PR, Muir JG (1999) Wheat bran affects the site of fermentation of resistant starch and luminal indexes related to colon cancer risk: a study in pigs. Gut 45:840-847 
Grootaert C, Van den Abbeele P, Marzorati M, Broekaert WF, Courtin CM, Delcour JA, Verstraete W, Van de Wiele T (2009) Comparison of prebiotic effects of arabinoxylan oligosaccharides and inulin in a simulator of the human intestinal microbial ecosystem. FEMS Microbio Ecol. 69:231-242 Harmsen HJM, Wildeboer-Veloo ACM, Grijpstra J, Knol J, Degener JE, Welling GW (2000) Development of 165 rRNA-based probes for the Coriobacterium group and the Atopobium cluster and their application for enumeration of coriobacteriaceaein human feces from volunteers of different age groups. Appl Environ Microbiol 66:4523-4527

Haskå L, Nyman M, Andersson R (2008) Distribution and characterisation of fructan in wheat milling fractions. J Cereal Sci 48:768-774

Hold GL, Schwiertz A, Aminov RI, Blaut M, Flint HJ (2003) Oligonucleotide probes that detect quantitatively significant groups of butyrate-producing bacteria in human feces. Appl Environ Microbiol 69:4320-4324

Hughes SA, Shewry PR, Li L, Gibson GR, Sanz ML, Rastall RA (2007) In vitro fermentation by human fecal microflora of wheat arabinoxylans. J Agric Food Chem 55:4589-4595

Hughes SA, Shewry PR, Gibson GR, McCleary BV, Rastall RA (2008) In vitro fermentation of oat and barley derived $\beta$-glucans by human faecal microbiota: in vitro fermentation of cereal $\beta$-glucans. FEMS Microbiol Ecol 64:482-493

JMares D, Stone B (1973) Studies on wheat endosperm i chemical composition and ultrastructure of the cell walls. Aust J Biol Sci. 26(4):793

Johansson L, Tuomainen P, Ylinen M, Ekholm P, Virkki L (2004) Structural analysis of water-soluble and-insoluble $\beta$-glucans of whole-grain oats and barley. Carbohydr Polym 58:267-274

Kim HJ, White PJ (2009) In vitro fermentation of oat flours from typical and high $\beta$-glucan oat lines. J Agric Food Chem 57:7529-7536

Langendijk PS, Schut F, Jansen GJ, Raangs GC, Kamphuis GR, Wilkinson MH, Welling GW (1995) Quantitative fluorescence in situ hybridization of Bifidobacterium spp. with genus-specific 16S rRNA-targeted probes and its application in fecal samples. Appl Environ Microbiol 61:3069-3075

Li W, Cui SW, Kakuda Y (2006) Extraction, fractionation, structural and physical characterization of wheat $\beta$-D-glucans. Carbohydr Polym 63:408-416

Manz W, Amann R, Ludwig W, Vancanneyt M, Schleifer K-H (1996) Application of a suite of $16 \mathrm{~S}$ rRNA-specific oligonucleotide probes designed to investigate bacteria of the phylum Cytophaga-Flavobacter-Bacteroides in the natural environment. Microbiology 142:1097-1106

Pryde SE, Duncan SH, Hold GL, Stewart CS, Flint HJ (2002) The microbiology of butyrate formation in the human colon. FEMS Microbiol Lett 217:133-139

Rycroft CE, Jones MR, Gibson GR, Rastall RA (2001a) A comparative in vitro evaluation of the fermentation properties of prebiotic oligosaccharides. J Appl Microbiol 91:878-887. https://doi.org/10.104 6/j.1365-2672.2001.01446.x
Rycroft CE, Jones MR, Gibson GR, Rastall RA (2001b) Fermentation properties of gentio-oligosaccharides. Lett Appl Microbiol 32:156-161. https://doi. org/10.1046/j.1472-765x.2001.00875.x

Salyers AA, Palmer JK, Wilkins TD (1997) Laminarinase (p8-glucanase) activity in bacteroides from the human colon. Appl Environ Microbiol 33(5):1118-1124

Shewry PR, Hey SJ (2015) The contribution of wheat to human diet and health. Food Energy Secur. 4:178-202

Siljeström M, Asp N-G (1985) Resistant starch formation during baking-effect of baking time and temperature and variations in the recipe. Z Für Lebensm-Unters Forsch. 181:4-8

Singh J (1997) Bifidobacterium longum, a lactic acid-producing intestinal bacterium inhibits colon cancer and modulates the intermediate biomarkers of colon carcinogenesis. Carcinogenesis 18:833-841

Steer T, Thane C, Stephen A, Jebb S (2008) Bread in the diet: consumption and contribution to nutrient intakes of British adults. Proc Nutr Soc 67(OCE8):E363

Stewart ML, Timm DA, Slavin JL (2008) Fructooligosaccharides exhibit more rapid fermentation than long-chain inulin in an in vitro fermentation system. Nutr Res 28:329-334

Van Craeyveld V, Swennen K, Dornez E, Van de Wiele T, Marzorati M, Verstraete W, Delaedt Y, Onagbesan O, Decuypere E, Buyse J et al (2008) Structurally different wheat-derived arabinoxylooligosaccharides have different prebiotic and fermentation properties in rats. J Nutr 138:2348-2355

Vanderhaeghen S, Lacroix C, Schwab C (2015) Methanogen communities in stools of humans of different age and health status and co-occurrence with bacteria. FEMS Microbiol Lett. 362(13):092

Walker AW, Duncan SH, McWilliam Leitch EC, Child MW, Flint HJ (2005) pH and peptide supply can radically alter bacterial populations and short-chain fatty acid ratios within microbial communities from the human colon. Appl Environ Microbiol 71:3692-3700

Wang Y, Ames NP, Tun HM, Tosh SM, Jones PJ, Khafipour E (2016) High molecular weight barley $\beta$-Glucan alters gut microbiota toward reduced cardiovascular disease risk. Front Microbiol. 7:129

Zanotti I, Turroni F, Piemontese A, Mancabelli L, Milani C, Viappiani A, Prevedini G, Sanchez B, Margolles A, Elviri L et al (2015) Evidence for cholesterollowering activity by Bifidobacterium bifidum PRL2010 through gut microbiota modulation. Appl Microbiol Biotechnol 99:6813-6829

\section{Publisher's Note}

Springer Nature remains neutral with regard to jurisdictional claims in published maps and institutional affiliations.

\section{Submit your manuscript to a SpringerOpen ${ }^{\circ}$ journal and benefit from:}

- Convenient online submission

- Rigorous peer review

- Open access: articles freely available online

- High visibility within the field

Retaining the copyright to your article

Submit your next manuscript at springeropen.com 